\title{
GEOGRAPHICAL STUDIES ON RHEUMATOID ARTHRITIS
}

\author{
BY
}

\author{
J. S. LAWRENCE, T. BEHREND, P. H. BENNETT, J. M. BREMNER, T. A. BURCH, \\ J. GOFTON, W. O'BRIEN, AND H. ROBINSON
}

From the Field Survey Units of the National Institutes of Health, Bethesda, Maryland, the Arthritis and Rheumatism Council, Manchester, England, the Medical University Poliklinik, MarburglLahn, West Germany, and the Canadian Arthritis and Rheumatism Society, Vancouver, British Columbia, Canada

Though it has been suggested that rheumatoid arthritis (RA) is influenced by climate and is less frequent in tropical climates, no reliable evidence has so far been forthcoming to confirm or refute this. The prevalence of the disease is known to increase with age, and it would, therefore, be expected that it would be less frequent in populations with a low life expectancy. In surveys of population samples aged 55 to 64 years in a number of Northern European countries, de Graaff, Laine, and Lawrence (1963) found no relationship to latitude; but since the range of latitude amounted to only $10^{\circ}$, these surveys could not exclude such a relationship. In a comparison of the same age group in populations in Leigh, England, and Pittsburgh, U.S.A., Cobb and Lawrence (1957) observed a rather lower prevalence in the latter. Sitaj, Niepel, Kostka, Trnavsky, and Sipos (1964) similarly found a lower prevalence in a rural sample in the region of Pieštany, Southern Czechoslovakia, than in the Northern European surveys.

On the other hand, Bunim, Burch, and O'Brien (1964) found no significant difference between the prevalence of probable and definite rheumatoid arthritis in the Bla:kfeet Indians living in Montana at a latitude of $48^{\circ} \mathrm{N}$. and the Pima Indians in Arizona at a latitude of $33^{\circ} \mathrm{N}$. If anything, the prevalence was slightly higher in the Pima Indians.

In a study of the Haida Indians on Queen Charlotte Islands, Canada, at a latitude of $54^{\circ} \mathrm{N}$., Gofton, Robinson, and Price (1964) similarly found a prevalence of probable and definite disease which was slightly less than, though not significantly different from, that in the other Amerindians. Indeed, there was a gradient of increasing prevalence from north to south (Table I).

To investigate further the influence of latitude, it was decided to examine populations living under widely different climatic conditions (Lawrence, Bremner, Ball, and Burch, 1966). Advantage was taken of a population study in a rural population near Kingston, Jamaica, by the Medical Research Council Epidemiological Unit under Dr. W. E. Miall, to include an examination of the musculo-skeletal system. The members of this sample, living at a latitude of $18^{\circ} \mathrm{N}$., were largely of Negro stock. Comparison was made with a population sample examined in Wensleydale in the North of England (latitude $54^{\circ} \mathrm{N}$.). Since both climate and race

TABLE I

PREVALENCE OF PROBABLE AND DEFINITE RHEUMATOID ARTHRITIS IN AMERINDIANS AGED 35 AND OVER, BY SEX (UNWEIGHTED MEANS)

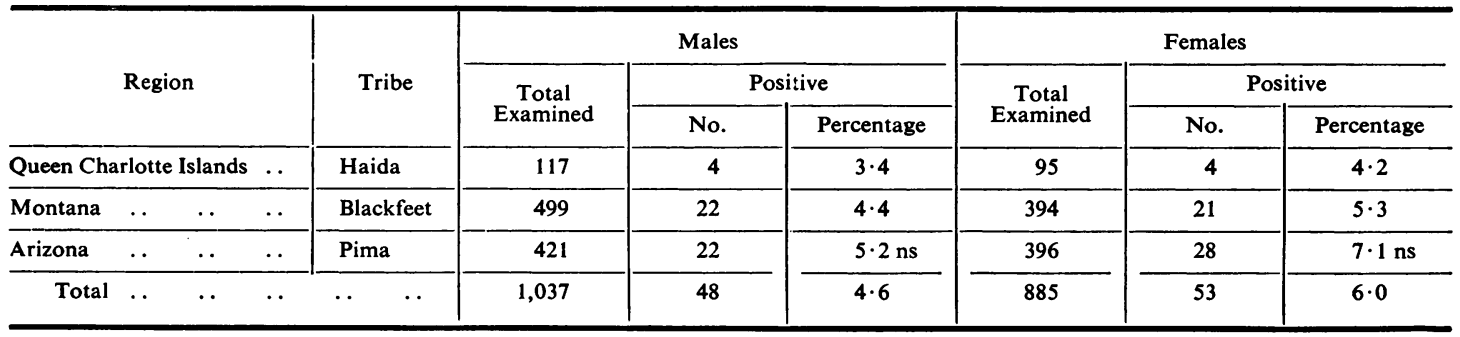


were different in these two populations, it was impossible to decide which was responsible for the greater prevalence in Jamaica. It was therefore decided to increase the scope of this study by comparing $x$ rays taken on a number of other population samples by workers in Europe and America. Thanks to the generous co-operation of these workers, this is now in progress and sufficient results are available for a preliminary analysis of the findings. Results on the remaining surveys will be considered in a later paper.

Completion Rate.-The numbers in each sample and the completion rates are shown in Table II. The completion rates were all at least 85 per cent. Most of the comparisons, however, will be based only on persons aged 35 to 64 years, since individuals of other ages were not examined in one or more of the surveys. The $x$ rays from six of these eight surveys were mixed together and were read blind by one observer (J.S.L.) during the years 1964-65, using the "Atlas of Standard Radiographs" (1963). The $x$ rays of the Haida Indians were read in 1963-64 mixed with the Wensleydale $x$ rays, which were thus read twice. Only the readings for hands and feet are so far available for all the surveys. Readings of the cervical $x$ rays have been completed in six of the surveys.

For further details of the method of survey, papers by the individual authors should be consulted (Lawrence and Bennett, 1960; Bremner, 1961; Robinson, Gofton, and Price, 1963; Bunim, 1963). The sera were examined for rheumatoid factor by the sheep cell agglutination test (SCAT) by Dr. J. Ball of Manchester University for the English, Canadian, and Jamaican surveys, by Dr. T. A. Burch of the National Institutes of Health for the Montana and Arizona surveys, and by Dr. T. Behrend for the Oberhörlen survey. The bentonite flocculation tests (BFT) for the populations of Arizona, Montana, and the Queen Charlotte Islands, and for a part of the Wensleydale sample were made by Dr. T. A. Burch the latex-fixation tests (LFT) for the Wensleydale survey by Dr. H. A. Valkenburg, and for the Watford? survey by Dr. A. Reading of the Canadian Red Cros永 Memorial Hospital, Taplow.

\section{Results}

Latitude (Table III, overleaf)

ARA Criteria for Rheumatoid Arthritis.-At first n relationship was apparent (Table IIIA). The greate est prevalence of probable (three or more criteria) and definite (five or more criteria) disease was found in the Jamaican population at $18^{\circ}$, the Queen Charlott Islands at $54^{\circ}$ had the lowest, and the Pima Indians if Arizona at $33^{\circ}$ had an intermediate value. Though the differences between Jamaica, the Queen Charlott Islands, and Watford are significant, this differencter and most of the other differences between the survey\& occurred in the probable RA group. Since observer error might be expected to play a greater part i⿹ defining probable than definite arthritis, it cannot be established that the regional variations in prevalenco were not due to observer difference unless confirmeg by the $x$-ray findings.

Radiological Changes.-Grade 3 to 4 ero arthritis in the hands or feet varied in prevalence from 0 per cent. in Watford to $1 \cdot 5$ per cent. in Wensleydâi] but the differences were not significant (Table IIIB When Grade 2 changes were included, certain ver弯 significant differences emerged, but they were unrelæ ted to latitude. The highest prevalence was found i⿱ Jamaica at $18^{\circ} \mathrm{N}$. and the lowest in Watford $51^{\circ} \mathrm{N}$., but further north, in the Queen Charlotte

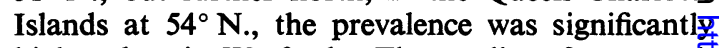
higher than in Watford. The gradient from north to south noted in the Amerindians, using the AR

TABLE II

COMPLETION RATE IN SURVEYS INCLUDED IN THIS STUDY $X$ Rays of Hands, Feet, and Cervical Spine taken in each age group

\begin{tabular}{|c|c|c|c|c|c|c|c|c|c|c|}
\hline \multicolumn{4}{|c|}{ Region } & \multirow{2}{*}{$\begin{array}{c}\text { Latitude } \\
54^{\circ} \\
54^{\circ} \\
53^{\circ} \\
51^{\circ} \\
50^{\circ} \\
48^{\circ} \\
33^{\circ} \\
18^{\circ}\end{array}$} & \multirow{2}{*}{$\begin{array}{r}\text { Total } \\
1,062 \\
492 \\
1,614 \\
496 \\
443 \\
1,255 \\
1,128 \\
600\end{array}$} & \multirow{2}{*}{$\begin{array}{c}\begin{array}{c}\text { Refused } \\
\text { or Not } \\
\text { Available }\end{array} \\
95 \\
56 \\
223 \\
75 \\
22 \\
154 \\
160 \\
64\end{array}$} & \multirow{2}{*}{$\begin{array}{c}\begin{array}{c}\text { No. } \\
\text { Examined }\end{array} \\
967 \\
436 \\
1,391 \\
421 \\
421 \\
1,101 \\
968 \\
536\end{array}$} & \multirow{2}{*}{$\begin{array}{c}\begin{array}{c}\text { No. } \\
\text { x-rayed }\end{array} \\
954 \\
436 \\
1,157 \\
413 \\
421 \\
1,095 \\
953 \\
529\end{array}$} & \multirow{2}{*}{$\begin{array}{c}\begin{array}{c}\text { Completion } \\
\text { Rate } \\
\text { (Percentage) }\end{array} \\
89 \\
89 \\
86 \\
85 \\
95 \\
88 \\
86 \\
89\end{array}$} & \multirow{2}{*}{$\begin{array}{c}\begin{array}{c}\text { Age } \\
\text { Group } \\
\text { Studied }\end{array} \\
15+ \\
15+ \\
15+ \\
15+ \\
15+ \\
30+ \\
30+ \\
35-64\end{array}$} \\
\hline $\begin{array}{l}\text { Wensleydale } \\
\text { Queen Charl } \\
\text { Leigh } \\
\text { Watford } \\
\text { Oberhörlen } \\
\text { Montana } \\
\text { Arizona } \\
\text { Jamaica }\end{array}$ & $\begin{array}{l}\text { e } \\
\text { rlotte } \\
\ldots \\
\ldots \\
\ldots \\
\ldots \\
\ldots\end{array}$ & $\begin{array}{l}\text { siands } \\
\therefore \\
\therefore \\
\ldots \\
\cdots \\
\cdots\end{array}$ & $\begin{array}{l}\cdots \\
\cdots \\
\cdots \\
\cdots \\
\cdots \\
\cdots\end{array}$ & & & & & & & \\
\hline
\end{tabular}


criteria, was not apparent with the radiological readings.

$X$ rays of the cervical spine have so far been read only in the European samples, the Haida Indians, and the Jamaicans (Table IIIB). They did not show the striking differences noted in the case of the hands and feet. The greatest prevalence was found in Oberhörlen, where it was shared equally by the sexes, but it was not significantly greater here than in other areas.

Rheumatoid Serum Factor.-The proportion with positive sheep cell agglutination tests (SCAT) varied considerably in various areas but the variations showed no relationship to latitude (Table IIIC). The highest percentage was found in Arizona which had significantly more than any of the other areas. Since the laboratory which conducted the tests in Arizona also conducted the tests on the Montana samples and as cross-checking was carried out with the other laboratory, this difference is unlikely to be due to technical bias.

Of the FII globulin tests, the BFT was performed in the Queen Charlotte Islands, Montana, Arizona, Jamaica, and part of Wensleydale, and the LFT in Wensleydale and Watford. Again there was no relationship to latitude (Table IIID). As in the case of the SCAT, the highest values were found in Arizona, 21 per cent. of whom had a positive testsignificantly more than in the other surveys both to the north and to the south. The BFT on the Pima and Blackfeet populations was performed in the same laboratory. A sample of each has been retested simultaneously and the difference confirmed.

\section{Ethnic Group}

Since it is clear that there is little or no relationship of any of the rheumatoid parameters to latitude, the populations were divided into the three ethnic groups: Amerindians, Jamaicans, and Caucasians (Table IV, overleaf).

ARA Criteria for Rheumatoid Arthritis.-The greatest prevalence of probable and/or definite disease was found in the Jamaicans, who had significantly more than the Amerindians or Caucasians (Table IVA). There was no difference in prevalence between the last two races. Definite rheurnatoid arthritis on the other hand had much the same prevalence in the three races.

Radiological Changes.-These similarly showed no great difference in prevalence in the more severe grades; but when grade 2 change was included, the Jamaicans had more erosive arthritis in the peripheral joints than the other two races in both sexes (Table
IVB). The Caucasians, in turn, had significanfly less than the Amerindians or Jamaicans. There wass, however, some overlap between the first two groups, the Oberhörlen population having almost as mueh as the Amerindians. This was mainly due to the high prevalence of erosive arthritis in males of this popuntion (Behrend and Lawrence, 1966). Of the males with erosive arthritis, ten had a past history $8 \mathrm{f}$ polyarthritis, and in two of these the onset was $\mathbb{I n}_{n}$ childhood.

Rheumatoid Serum Factor.-The SCAT (Tabte IVC) was most often positive in the Amerindians, who had significantly more positive tests than tire Jamaicans or Caucasians, but there was considerabie overlap between the different population samples $\overline{\text { an }}$ these two groups.

The FII globulin tests were also most frequently positive in the Amerindians, but were least so in the Caucasians, who had significantly fewer positives than either of the others. There was, however, considerable variation within the ethnic groups, ant it would seem unlikely that race is of prime impotsance in determining the titres of these factors (Taßge IVD).

\section{Discussion}

The concept that rheumatoid arthritis is ra on tropical countries is not borne out of these studies. Data obtained with the ARA criteria indicate increasing prevalence from north to south in the American surveys. Since these surveys are based on data collected by three different observers, the results may have been influenced by observer differences in interpretation. Two observers took part both the Montana and Arizona surveys and another in both the Montana and Jamaican surveys, so that the differences in prevalence observed in these th. pairs of surveys are likely to be more genuine, buit intra-observer differences cannot be excluded. The very low prevalence of 1 per cent. probable and $\bar{\beta}$ r definite rheumatoid arthritis found by Blumberg, Bloch, Black, and Dotter (1961) in Alaska wougd support this gradient, but doubt is cast on it when the European surveys are included, and particulagly when the radiological changes are studied. A ractal grouping appears more meaningful but until mofe population samples of Negroes have been studied, this cannot be conclusive. A greater prevalence of minimal changes was found in the Jamaicans than the Amerindians and in the Amerindians than in the Caucasians. This would suggest that two aet logical factors are present-one determining incelence, the other severity. Either or both of these could be genetically or environmentally determined. 
A relationship of incidence, or of onset, to infection has been suggested by a number of studies (Short, Bauer, and Reynolds, 1957; Lawrence and Bennett, 1960; Valkenburg, 1966). Evidence relating severity and prognosis to the rheumatoid serum factors, which appear also to have some association with infection, suggests that the second factor might also be infective. On the other hand, genetic causes have been suggested both for clinical arthritis and for rheumatoid serum factors from evidence produced by family studies, and there is evidence that these show independent aggregation in families (Lawrence and Ball, 1958). Infections within the family could possibly explain these aggregations and the predominance of positive SCATS in the offspring in families favours this explanation of the aggregation of rheumatoid factors (Lawrence, 1963).

A low titre of rheumatoid serum factors in a

LATITUde RELATED TO (A) PERCENTAGE PREVALENCE OF RHEUMATOID ARTHRITIS, (B) RADIOLOGICAL EVIDEN\&E 0 TESTS IN PERSONS AGED 35-64 YEAR

\begin{tabular}{|c|c|c|c|c|c|c|c|c|c|c|}
\hline \multirow{4}{*}{\multicolumn{3}{|c|}{ Region }} & & \multirow{4}{*}{ Latitude } & \multirow{2}{*}{\multicolumn{3}{|c|}{$\begin{array}{l}\text { (A) } \\
\text { Rheumatoid Arthritis }\end{array}$}} & \multirow{2}{*}{\multicolumn{3}{|c|}{$\frac{\begin{array}{c}(\mathrm{B}) \\
\text { Radiological Erosions }\end{array}}{\text { Hands and Feet }}$}} \\
\hline & & & & & & & & & & \\
\hline & & & & & \multirow{2}{*}{$\begin{array}{c}\text { No. } \\
\text { Examined }\end{array}$} & \multirow{2}{*}{$\begin{array}{l}\text { Probable } \\
\text { and } \\
\text { Definite }\end{array}$} & \multirow{2}{*}{ Definite } & \multirow{2}{*}{$\underset{x \text {-rayed }}{\text { Total }}$} & \multicolumn{2}{|c|}{ Grade (Percentage) } \\
\hline & & & & & & & & & $2-4$ & \\
\hline Wensleydale & & $\cdots$ & $\cdots$ & $54^{\circ}$ & 465 & $5 \cdot 7$ & $1 \cdot 4$ & 462 & $3 \cdot 5 * *$ & \\
\hline \multicolumn{3}{|c|}{ Queen Charlotte Islands } & $\cdots$ & $54^{\circ}$ & 173 & $3 \cdot 2^{*}$ & $1 \cdot 4$ & 172 & $7 \cdot 7^{*}$ & \\
\hline Leigh & . & . & $\ldots$ & $53^{\circ}$ & 672 & $4 \cdot 9$ & $1 \cdot 1$ & 506 & $2 \cdot 6^{* *}$ & $0 \cdot 5$ \\
\hline Watford & $\cdots$ & $\cdots$ & $\cdots$ & $51^{\circ}$ & 200 & $3 \cdot 6^{*}$ & $0 \cdot 5$ & 198 & $0 \cdot 9 *$ & $0 \cdot \mathrm{c}$ \\
\hline Oberhörlen & $\cdots$ & $\cdots$ & $\cdots$ & $50^{\circ}$ & 210 & $4 \cdot 3$ & $2 \cdot 2$ & 210 & $6 \cdot 2$ & $1 \cdot 1$ \\
\hline Montana & $\cdots$ & $\cdots$ & $\cdots$ & $48^{\circ}$ & 729 & $4 \cdot 8$ & $1 \cdot 8$ & 759 & $4 \cdot 1$ & \\
\hline Arizona & $\ldots$ & $\ldots$ & $\cdots$ & $33^{\circ}$ & 635 & $6 \cdot 0$ & $2 \cdot 4$ & 632 & $8 \cdot 3$ & 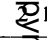 \\
\hline Jamaica & . & $\cdots$ & $\ldots$ & $18^{\circ}$ & 529 & $11 \cdot 0^{*}$ & $1 \cdot 7 \mathrm{~ns}$ & 528 & $12 \cdot 1^{* *}$ & $\frac{\bar{\phi}}{2}$ \\
\hline
\end{tabular}

${ }^{*} \mathrm{P}<0.05>0.01 \quad$ ns $=$ not significant $\quad * * \mathrm{P}<0.01$

ETHNIC GROUP RELATED TO (A) ARA CRITERIA (ACTIVE), (B) RADIOLOGICAL EVIDENCE OF EROSIONS IN HANDS AND

\begin{tabular}{|c|c|c|c|c|c|c|c|c|}
\hline & & & \multicolumn{3}{|c|}{$\begin{array}{l}\text { (A) } \\
\text { Rheumatoid Arthritis }\end{array}$} & \multicolumn{3}{|c|}{ Radiological Erosions in Hands and Feet $\frac{3}{2}$} \\
\hline \multirow{3}{*}{\multicolumn{3}{|c|}{ Ethnic Group }} & \multirow{3}{*}{ Total } & \multirow{3}{*}{$\begin{array}{l}\text { Probable } \\
\text { and } \\
\text { Definite }\end{array}$} & \multirow{3}{*}{ Definite } & \multicolumn{3}{|c|}{ Male } \\
\hline & & & & & & Total & Grad & ge) $\frac{\text { ¿ }}{2}$ \\
\hline & & & & & & $x$-rayed & $2-4$ & $3-4 \bar{\sigma}$ \\
\hline \multirow{4}{*}{ Amerindians } & Haida $\quad .$. & . & 173 & $3 \cdot 2$ & $1 \cdot 4$ & 97 & $9 \cdot 3$ & $1 \cdot \frac{5}{30}$ \\
\hline & Blackfeet & .. & 729 & $4 \cdot 8$ & $1 \cdot 8$ & 431 & $5 \cdot 5$ & $1 \cdot 0 \frac{0}{3}$ \\
\hline & Pima $\quad .$. & .. & 635 & $6 \cdot 0$ & $2 \cdot 4$ & 300 & $7 \cdot 9$ & 0.70 \\
\hline & Total $\quad .$. & .. & 1,537 & $4 \cdot 7^{* *}$ & 1.9 & 828 & $7 \cdot 6$ & $1 \cdot 0$ \\
\hline Jamaicans & . & .. & 529 & $11 \cdot 0 * *$ & $1 \cdot 7$ & 260 & $13 \cdot 0$ & $1 \cdot 5$ 을. \\
\hline \multirow{5}{*}{ Caucasians } & Oberhörlen & .. & 210 & $4 \cdot 3$ & $2 \cdot 2$ & 90 & $9 \cdot 5$ & $2 \cdot 2 \mathrm{~N}$ \\
\hline & Watford .. & .. & 200 & $3 \cdot 6$ & $0 \cdot 5$ & 97 & $0 \cdot 8$ & $0.0 \mathrm{~N}$ \\
\hline & Leigh $\quad .$. & . & 672 & $4 \cdot 9$ & $1 \cdot 1$ & 285 & $2 \cdot 6$ & $0.4 \mathrm{~N}$ \\
\hline & Wensleydale & . & 465 & $5 \cdot 7$ & $1 \cdot 4$ & 223 & $3 \cdot 0$ & $1 \cdot 0 \sigma$ \\
\hline & Total $\quad .$. & $\cdots$ & 1,547 & $4 \cdot 6^{* *}$ & $1 \cdot 3$ & 695 & $2 \cdot 1^{* *}$ & 0.5 \\
\hline \multicolumn{9}{|c|}{${ }^{*} \mathrm{P}<0.05>0.01$} \\
\hline
\end{tabular}


population, particularly of those reacting with rabbit globulin, might reflect a favourable environment and might explain why the Jamaicans had little severe change. In the Amerindians the relatively high titres could result in a moderate prevalence of arthritis in a population with little genetic predisposition. Such a low predisposition frequency might have resulted from selection against those carrying the gene(s) in previous generations. Evidence for the

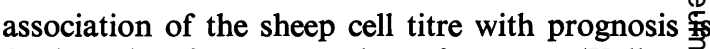
forthcoming from a number of sources (Kellgre 1957; Duthie, Brown, Knox, and Thompson, 195क;: Otten and Boerma, 1959; Ball and Lawrence, 1963) It is interesting to speculate whether or not the absence of a difference in the prevalence of the mote severe grades of rheumatoid arthritis in the popula tions studied may depend on the striking of a balance between genetic predisposition to clinical arthritos

III

EROSIONS IN THE HANDS, FEET, AND CERVICAL SPINE, (C) SHEEP CELL AGGLUTINATION TEST, AND (D) FII GLOBULIN UNWEIGHTED MEANS OF'THREE AGE GROUPS)

\begin{tabular}{|c|c|c|c|c|c|c|c|}
\hline \multicolumn{3}{|c|}{ Radiological Erosions } & \multirow{2}{*}{\multicolumn{2}{|c|}{$\begin{array}{c}\text { (C) } \\
\text { Sheep Cell } \\
\text { Agglutination Test }\end{array}$}} & \multirow{2}{*}{\multicolumn{3}{|c|}{$\begin{array}{l}\text { (D) } \\
\text { FII Globulin Tests }\end{array}$}} \\
\hline \multicolumn{3}{|c|}{ Cervical Spine } & & & & & \\
\hline \multirow{2}{*}{$\underset{x \text {-rayed }}{\text { Total }}$} & \multicolumn{2}{|c|}{ Grade (Percentage) } & \multirow{2}{*}{$\begin{array}{l}\text { Total } \\
\text { Tested }\end{array}$} & \multirow{2}{*}{$\begin{array}{l}\text { Percentage } \\
\text { Positive } \\
\text { Tests }\end{array}$} & \multirow{2}{*}{$\begin{array}{l}\text { Total } \\
\text { Tested }\end{array}$} & \multirow{2}{*}{ Test } & \multirow{2}{*}{$\begin{array}{l}\text { Percentage } \\
\text { Positive } \\
\text { Tests }\end{array}$} \\
\hline & $2-4$ & 3-4 & & & & & \\
\hline 464 & $2 \cdot 5$ & 0.5 & 464 & $2 \cdot 2^{* *}$ & $\begin{array}{l}442 \\
196\end{array}$ & $\begin{array}{l}\text { LFT } \\
\text { BFT }\end{array}$ & $\begin{array}{l}6 \cdot 7 \\
5 \cdot 5^{* *}\end{array}$ \\
\hline 172 & $1 \cdot 5$ & 0.0 & 172 & $3 \cdot 1$ & 172 & BFT & $8 \cdot 3^{* *}$ \\
\hline 588 & $2 \cdot 1$ & $0 \cdot 2$ & 698 & $4 \cdot 9$ & - & & ब \\
\hline 192 & $1 \cdot 5$ & 0.0 & 178 & $1 \cdot 0$ & 178 & LFT & $0 \cdot 0$ \\
\hline 210 & $4 \cdot 9 \mathrm{~ns}$ & 0.0 & 210 & $4 \cdot 0$ & - & & \\
\hline- & & & 722 & $5 \cdot 8$ & 729 & BFT & $5 \cdot 3 * \frac{10}{0}$ \\
\hline- & & & 633 & $9 \cdot 2^{* *}$ & 635 & BFT & $20 \cdot 5 *$ 는. \\
\hline 526 & $3 \cdot 1$ & 0.0 & 505 & $1 \cdot 6^{* *}$ & 500 & BFT & $7 \cdot 6 * * \underset{?}{?}$ \\
\hline
\end{tabular}

IV

(C) SHEEP CELL AGGLUTINATION TEST, AND (D) RHEUMATOID FACTOR IN PERSONS AGED 35-64 YEARS (UNWEIGHTED MEANE)

(B)

Radiological Erosions in Hands and Feet

\begin{tabular}{|c|c|c|c|c|c|c|c|c|c|}
\hline \multicolumn{6}{|c|}{ Radiological Erosions in Hands and Feet } & \multicolumn{2}{|c|}{ Sheep Cell Agglutination Test } & \multicolumn{2}{|c|}{ FII Globulin Test } \\
\hline \multicolumn{3}{|c|}{ Female } & \multicolumn{3}{|c|}{ Both Sexes } & \multirow{3}{*}{$\begin{array}{c}\text { Total } \\
\text { Tested }\end{array}$} & \multirow{3}{*}{$\begin{array}{l}\text { Percentage } \\
\text { Positive } \\
\text { Tests }\end{array}$} & \multirow{3}{*}{$\begin{array}{c}\text { Total } \\
\text { Tested }\end{array}$} & \multirow{3}{*}{$\begin{array}{c}\text { Percentage } \\
\text { Positive } \\
\text { Tests } \\
\end{array}$} \\
\hline \multirow{2}{*}{$\underset{x \text {-rayed }}{\text { Total }}$} & \multicolumn{2}{|c|}{ Grade (Percentage) } & \multirow{2}{*}{$\underset{x \text {-rayed }}{\text { Total }}$} & \multicolumn{2}{|c|}{ Grade (Percentage) } & & & & \\
\hline & $2-4$ & $3-4$ & & $2-4$ & $3-4$ & & & & \\
\hline 75 & $5 \cdot 3$ & $1 \cdot 2$ & 172 & $7 \cdot 7$ & $1 \cdot 3$ & 172 & $3 \cdot 1$ & 172 & $8 \cdot 3$ \\
\hline 328 & $2 \cdot 3$ & 0.6 & 759 & $4 \cdot 1$ & $0 \cdot 8$ & 722 & $5 \cdot 8$ & 729 & $5 \cdot 5 * *\}$ \\
\hline 332 & $8 \cdot 8$ & $3 \cdot 4$ & 632 & $8 \cdot 3$ & $2 \cdot 1$ & 633 & $9 \cdot 2$ & 635 & $20 \cdot 5^{* *}$ 笛 \\
\hline 735 & $5 \cdot 5$ & $1 \cdot 7$ & 1,563 & $6 \cdot 7^{* *}$ & $1 \cdot 4$ & 1,527 & $6 \cdot 9 * *$ & 1,536 & $12 \cdot 0^{* *} \frac{\square}{2}$ \\
\hline 268 & $11 \cdot 3$ & $0 \cdot 0$ & 528 & $12 \cdot 1^{* *}$ & $0 \cdot 8$ & 505 & $1 \cdot 6^{* *}$ & 500 & $7 \cdot 6^{*}=$ \\
\hline 120 & $3 \cdot 0$ & 0.0 & 210 & $6 \cdot 3$ & $1 \cdot 1$ & 210 & $3 \cdot 2$ & - & क \\
\hline 101 & $1 \cdot 1$ & 0.0 & 198 & 0.9 & 0.0 & 178 & $1 \cdot 0$ & 178 & $0 \cdot 0$ \\
\hline 321 & $2 \cdot 5$ & 0.6 & 606 & $2 \cdot 6$ & 0.5 & 698 & $4 \cdot 9$ & - & $\omega$ \\
\hline 239 & $3 \cdot 7$ & $1 \cdot 8$ & 462 & $3 \cdot 5$ & $1 \cdot 5$ & 464 & $2 \cdot 2$ & 442 & $6.7 \stackrel{0}{2}$ \\
\hline 781 & $2 \cdot 4$ & 0.6 & 1,476 & $3 \cdot 3 * *$ & 0.8 & 1,550 & $2 \cdot 8$ & 620 & $3 \cdot 4 * * \frac{\mathbb{C}}{\frac{1}{D}}$ \\
\hline
\end{tabular}

(C)

Sheep Cell Agglutination Test

\begin{tabular}{|c|c|c|c|c|c|c|c|c|c|}
\hline \multicolumn{6}{|c|}{ Radiological Erosions in Hands and Feet } & \multicolumn{2}{|c|}{ Sheep Cell Agglutination Test } & \multicolumn{2}{|c|}{ FII Globulin Test } \\
\hline \multicolumn{3}{|c|}{ Female } & \multicolumn{3}{|c|}{ Both Sexes } & \multirow{3}{*}{$\begin{array}{c}\text { Total } \\
\text { Tested }\end{array}$} & \multirow{3}{*}{$\begin{array}{l}\text { Percentage } \\
\text { Positive } \\
\text { Tests }\end{array}$} & \multirow{3}{*}{$\begin{array}{c}\text { Total } \\
\text { Tested }\end{array}$} & \multirow{3}{*}{$\begin{array}{c}\text { Percentage } \\
\text { Positive } \\
\text { Tests } \\
\end{array}$} \\
\hline \multirow{2}{*}{$\underset{x \text {-rayed }}{\text { Total }}$} & \multicolumn{2}{|c|}{ Grade (Percentage) } & \multirow{2}{*}{$\underset{x \text {-rayed }}{\text { Total }}$} & \multicolumn{2}{|c|}{ Grade (Percentage) } & & & & \\
\hline & $2-4$ & $3-4$ & & $2-4$ & $3-4$ & & & & \\
\hline 75 & $5 \cdot 3$ & $1 \cdot 2$ & 172 & $7 \cdot 7$ & $1 \cdot 3$ & 172 & $3 \cdot 1$ & 172 & $8 \cdot 3$ \\
\hline 328 & $2 \cdot 3$ & 0.6 & 759 & $4 \cdot 1$ & $0 \cdot 8$ & 722 & $5 \cdot 8$ & 729 & $5 \cdot 5 * *\}$ \\
\hline 332 & $8 \cdot 8$ & $3 \cdot 4$ & 632 & $8 \cdot 3$ & $2 \cdot 1$ & 633 & $9 \cdot 2$ & 635 & $20 \cdot 5^{* *}$ 笛 \\
\hline 735 & $5 \cdot 5$ & $1 \cdot 7$ & 1,563 & $6 \cdot 7^{* *}$ & $1 \cdot 4$ & 1,527 & $6 \cdot 9 * *$ & 1,536 & $12 \cdot 0^{* *} \frac{\square}{2}$ \\
\hline 268 & $11 \cdot 3$ & $0 \cdot 0$ & 528 & $12 \cdot 1^{* *}$ & $0 \cdot 8$ & 505 & $1 \cdot 6^{* *}$ & 500 & $7 \cdot 6^{*}=$ \\
\hline 120 & $3 \cdot 0$ & 0.0 & 210 & $6 \cdot 3$ & $1 \cdot 1$ & 210 & $3 \cdot 2$ & - & क \\
\hline 101 & $1 \cdot 1$ & 0.0 & 198 & 0.9 & 0.0 & 178 & $1 \cdot 0$ & 178 & $0 \cdot 0$ \\
\hline 321 & $2 \cdot 5$ & 0.6 & 606 & $2 \cdot 6$ & 0.5 & 698 & $4 \cdot 9$ & - & $\omega$ \\
\hline 239 & $3 \cdot 7$ & $1 \cdot 8$ & 462 & $3 \cdot 5$ & $1 \cdot 5$ & 464 & $2 \cdot 2$ & 442 & $6.7 \stackrel{0}{2}$ \\
\hline 781 & $2 \cdot 4$ & 0.6 & 1,476 & $3 \cdot 3 * *$ & 0.8 & 1,550 & $2 \cdot 8$ & 620 & $3 \cdot 4 * * \frac{\mathbb{C}}{\frac{1}{D}}$ \\
\hline
\end{tabular}


and the rheumatoid fastor titres in the population.

Kay and Bach (1965) have shown that rheumatoid females are less fertile than others, and Dixon and Kay (1964) that their siblings have a higher mortality under the age of 16 . They have suggested that this excludes a genetic cause. It is possible, however, that this increase of mortality occurs only when rheumatoid factors are present in a high proportion of the population, and that at other times those who are genetically predisposed have an increased survival.

It must be considered whether the grade 2 erosive arthritis in the hands and/or feet, which was so prevalent in the Jamaican and Amerindian populations, may be non-rheumatoid. The greater prevalence in males in the Amerindians suggests that spondylitis or Reiter's disease may have been responsible. If spondylitis were involved, a higher prevalence would be expected in the younger age groups in males. This was, in fact, found more frequently in the Amerindian and Jamaican populations than in Leigh which is known to have a low prevalence of spondylitis (Table V). It was particularly marked in the Haida Indians in Queen Charlotte Islands who had a high prevalence of erosive arthritis from age 25 onwards. Spondylitis, moreover, is known to be particularly common in this sample and, in fazt, of the ten cases of spondylitis in this population, six had minimal erosive arthritis (Gofton and others, 1964). The Jamaican sample did not cover a sufficient age range to determine this point, but spondylitis was not as frequent in this population as in the Haidas or the Pimas or in Wensleydale. A history of urethritis was frequent in males in Jamaica, but was no more so in those with erosive arthritis than in those without. Similarly, yaws, a disease which is known to be associated with synovitis of the knees and ankles and with pain and swelling of the interphalangeal joints (Turner, 1959), though common in childhood in Jamaica, was no more so than in those with arthritis.

Trauma is known to give rise to erosions resembling those of rheumatoid arthritis (Crock, 1964), but a history of injury was not more frequent in the Jamaicans with erosive arthritis. The minimal changes in this population were found mainly in the feet (Table VI), particularly in the males, but both sexes had significantly more than the population in Montana. Since most Jamaicans walk barefoot, minor trauma may well have played a part. Erosions of the hands were not significantly more common in the Jamaicans than in the Amerindians. Trauma to the feet, however, cannot completely explain the

TABLE $\mathrm{V}$

PERCENTAGE WITH RADIOLOGICAL EROSIVE ARTHRITIS OF THE HANDS AND FEET IN MALES IN THE INDIAN, JAMAICAN, AND LEIGH SURVEYS, BY AGE GROUP

\begin{tabular}{|c|c|c|c|c|c|c|c|c|c|c|}
\hline \multirow{2}{*}{$\begin{array}{l}\text { Age } \\
\text { Group } \\
\text { (yrs) }\end{array}$} & \multicolumn{2}{|c|}{ Queen Charlotte } & \multicolumn{2}{|c|}{ Montana } & \multicolumn{2}{|c|}{ Arizona } & \multicolumn{2}{|c|}{ Jamaica } & \multicolumn{2}{|c|}{ Leigh } \\
\hline & $\underset{x \text {-rayed }}{\text { Total }}$ & $\begin{array}{l}\text { Grade 2-4 } \\
\text { (Percent.) }\end{array}$ & $\begin{array}{c}\text { Total } \\
x \text {-rayed }\end{array}$ & $\begin{array}{l}\text { Grade 2-4 } \\
\text { (Percent.) }\end{array}$ & $\begin{array}{c}\text { Total } \\
x \text {-rayed }\end{array}$ & $\begin{array}{l}\text { Grade } 2-4 \\
\text { (Percent.) }\end{array}$ & $\begin{array}{c}\text { Total } \\
x \text {-rayed }\end{array}$ & $\begin{array}{l}\text { Grade 2-4 } \\
\text { (Percent.) }\end{array}$ & $\underset{x \text {-rayed }}{\text { Total }}$ & $\begin{array}{l}\text { Grade 2-4 } \\
\text { (Percent.) }\end{array}$ \\
\hline $\begin{array}{l}15-24 \\
25-34 \\
35-44 \\
45-54 \\
55-64 \\
65+\end{array}$ & $\begin{array}{l}80 \\
42 \\
38 \\
33 \\
26 \\
24\end{array}$ & $\begin{array}{r}0 \\
12 \\
11 \\
6 \\
12 \\
40\end{array}$ & $\begin{array}{r}1 \overline{1} \\
167 \\
145 \\
119 \\
92\end{array}$ & $\begin{array}{r}- \\
1 \\
5 \\
4 \\
8 \\
10\end{array}$ & $\begin{array}{r}\overline{57} \\
116 \\
92 \\
92 \\
116\end{array}$ & $\begin{array}{r}-0 \\
5 \\
7 \\
12 \\
21\end{array}$ & $\begin{array}{l}- \\
88 \\
84 \\
88 \\
-\end{array}$ & $\begin{array}{l}- \\
13 \\
10 \\
17 \\
-\end{array}$ & $\begin{array}{r}127 \\
87 \\
92 \\
110 \\
83 \\
83\end{array}$ & $\begin{array}{l}0 \\
1 \\
2 \\
0 \cdot 9 \\
5 \\
12\end{array}$ \\
\hline Total & 243 & & 624 & & 473 & & 260 & & 582 & \\
\hline
\end{tabular}

TABLE VI

DISTRIBUTION OF RADIOLOGICAL EROSIVE ARTHRITIS IN THE HANDS AND FEET IN PERSONS AGED 35-64 IN THE AMERINDIAN AND JAMAICAN SURVEYS, BY SEX

\begin{tabular}{|c|c|c|c|c|c|c|c|c|}
\hline \multirow{2}{*}{$\underset{x \text {-rayed }}{\text { Joints }}$} & \multirow{2}{*}{\multicolumn{3}{|c|}{ Region }} & \multirow{2}{*}{ Latitude } & \multicolumn{2}{|c|}{ Males } & \multicolumn{2}{|c|}{ Females } \\
\hline & & & & & $\underset{x \text {-rayed }}{\text { Total }}$ & $\begin{array}{c}\text { Grade } 2-4 \\
\text { (Percentage) }\end{array}$ & $\underset{x \text {-rayed }}{\text { Total }}$ & $\begin{array}{c}\text { Grade } 2-4 \\
\text { (Percentage) }\end{array}$ \\
\hline \multirow[t]{2}{*}{ Hands } & $\begin{array}{l}\text { Queen Charlo } \\
\text { Montana } \\
\text { Arizona }\end{array}$ & $\begin{array}{c}\text { Islands } \\
\ldots \\
\ldots\end{array}$ & $\begin{array}{l}\cdots \\
\cdots \\
\cdots\end{array}$ & $\begin{array}{l}54^{\circ} \\
48^{\circ} \\
33^{\circ}\end{array}$ & $\begin{array}{r}97 \\
431 \\
300\end{array}$ & $\begin{array}{l}5 \cdot 1 \mathrm{~ns} \\
4 \cdot 4 \mathrm{~ns} \\
4 \cdot 4 \mathrm{~ns}\end{array}$ & $\begin{array}{r}75 \\
327 \\
332\end{array}$ & $\begin{array}{l}1 \cdot 2 \mathrm{~ns} \\
1 \cdot 4 \mathrm{~ns} \\
4 \cdot 4 \mathrm{~ns}\end{array}$ \\
\hline & Jamaica & . & . & $18^{\circ}$ & 260 & $4 \cdot 2 \mathrm{~ns}$ & 268 & $5 \cdot 6 \mathrm{~ns}$ \\
\hline \multirow[t]{2}{*}{ Feet } & $\begin{array}{l}\text { Queen Charlo } \\
\text { Montana } \\
\text { Arizona }\end{array}$ & $\begin{array}{c}\text { Islands } \\
\ldots \\
\ldots\end{array}$ & $\begin{array}{l}\cdots \\
\cdots \\
\cdots\end{array}$ & $\begin{array}{l}54^{\circ} \\
48^{\circ} \\
33^{\circ} \\
\end{array}$ & $\begin{array}{r}97 \\
430 \\
299\end{array}$ & $\begin{array}{l}5 \cdot 6 \\
2 \cdot 6 * * \\
3 \cdot 4\end{array}$ & $\begin{array}{r}75 \\
326 \\
330\end{array}$ & $\begin{array}{l}5 \cdot 4 \\
1 \cdot 5^{* *} \\
6 \cdot 4\end{array}$ \\
\hline & Jamaica & . & $\ldots$ & $18^{\circ}$ & 260 & $12 \cdot 6 * *$ & 268 & $7 \cdot 9 * *$ \\
\hline
\end{tabular}


greatet prevalence of erosive arthritis in the Jamaicans since they also have significantly more arthritis in the hands than the Caucasians (Table VII).

TABLE VII

EROSIVE ARTHRITIS OF THE HANDS RELATED TO ETHNIC GROUP IN PERSONS AGED 35-64 (WEIGHTED MEAN)

\begin{tabular}{|c|c|c|c|c|}
\hline \multirow{2}{*}{\multicolumn{2}{|c|}{ Ethnic Group }} & \multirow{3}{*}{$\begin{array}{c}\begin{array}{c}\text { Total } \\
x \text {-rayed }\end{array} \\
172 \\
758 \\
632\end{array}$} & \multicolumn{2}{|c|}{$\begin{array}{c}\text { Grade of Erosive } \\
\text { Arthritis (Percentage) }\end{array}$} \\
\hline & & & $2-4$ & $3-4$ \\
\hline \multirow[t]{2}{*}{ Amerindians } & $\begin{array}{l}\text { Haida } \\
\text { Blackfeet } \\
\text { Pima }\end{array}$ & & $\begin{array}{l}3 \cdot 1 \\
2 \cdot 9 \\
4 \cdot 5\end{array}$ & $\begin{array}{l}0 \cdot 3 \\
0 \cdot 6 \\
1 \cdot 3\end{array}$ \\
\hline & Total & 1,562 & $3 \cdot 5$ & $0 \cdot 7$ \\
\hline Jamaicans & . & 528 & $4 \cdot 9 *$ & 0.0 \\
\hline \multirow[t]{2}{*}{ Caucasians } & $\begin{array}{l}\text { Oberhörlen } \\
\text { Watford } \\
\text { Leigh } \\
\text { Wensleydale }\end{array}$ & $\begin{array}{l}210 \\
198 \\
607 \\
463\end{array}$ & $\begin{array}{l}3 \cdot 4 \\
0 \cdot 9 \\
1 \cdot 8 \\
2 \cdot 6\end{array}$ & $\begin{array}{l}1 \cdot 1 \\
0 \cdot 0 \\
0 \cdot 4 \\
1 \cdot 2\end{array}$ \\
\hline & Total & 1,478 & $2 \cdot 1^{*}$ & 0.6 \\
\hline
\end{tabular}

\section{Summary}

The prevalence of rheumatoid arthritis has been compared in eight population samples in America and Europe, in which routine $x$ rays were taken of the hands and feet. All the $x$ rays were read by one observer.

No relationship to latitude was discovered.

The prevalence of "definite" arthritis was not significantly different in the three racial groups included in these surveys, but "probable" disease was more common in the Negro population in Jamaica than in the Amerindians or Caucasians.

Radiological evidence of erosive arthritis was more frequent in the Jamaican than in the Amerindian, and in the Amerindian than in the Caucasian.

Serological tests for rheumatoid factor were more often positive in the Amerindian and erosive changes more severe.

The implications of these findings are discussed.

\section{REFERENCES}

Ball, J., and Lawrence, J. S. (1963). Ann. rheum. Dis., 22, 311.

Behrerd, T., and Lawrence, J. S. (1966). "Proc. XI Congr. Int. League against Rheumatism."

Blumberg, B. S., Bloch, K. J., Black, R. L., and Dotter, C. (1961). Arthr. and Rheum., 4, 325.
Bremner, J. M. (1961). Ann. rheum. Dis., 20, 149.

Bunim, J. J. (1963). Arthr. and Rheum., 6, 482.

- Burch, T. A., and O'Brien, W. M. (1964). Bull. rheum Dis., 15, 349.

Cobb, S., and Lawrence, J. S. (1957). Bull. rheum. Dis., 7. 133.

Crock, H. V. (1964). J. Bone Jt Surg., 46B, 530.

Dixon, A. St. J., and Kay, A. (1964). "Arthritis and Rheumatism Council Annual Report", p. 54.

Duthie, J. J. R., Browe, P. E., Knox, J. D. E., and Thompson, M. (1957). Ann. rheum. Dis., 16, 411.

Gofton, J. P., Robinson, H. S., and Price, G. E. (1964). Ibid., 23, 365 .

de Graaff, R., Laine, I., and Lawrence, J.S. (1963). In "The Epidemiology of Chronic Rheumatism", ed. J. H. Kellgren, M. R. Jeffrey, and J. Ball. Blackwell, Oxford.

Kay, A., and Bach, F. (1965). Ann. rheum. Dis., 24, 169. Kellgren, J. H. (1957). Brit. med. J., 1, 850.

Jeffrey, M., and Ball, J. (eds.), (1963). "Epidemiology of Chronic Rheumatism", vol. 2. Blackwell, Oxford.

Lawrence, J. S. (1963). Rev. Med., $10,1$.

and Ball, J. (1958). Ann. rheum. Dis., 17, 160.

and Bennett, P. H. (1960). Ibid., 19, 20.

—, Bremner, J. M., Ball, J., and Burch, T. A. (1966). Ibid., 25, 59.

Otten, H. A., and Boerma, F. W. (1959). Ibid., 18, 24.

Robinson, H. S., Gofton, J. P., and Price, G. E. (1963). Ibid., 22, 232.

Sit'aj, S., Niepel, G., Kostka, D., Trnavsky, K., and Sipos, J. (1964). Bratisl. lek. Listy., 44, 16.

Short, C. L., Bauer, W., and Reynolds, W. E. (1957). "Rheumatoid Arthritis". Howard University Press, Cambridge, Mass.

Turner, L. H. (1959). "Notes on the Treponematoses", p. 125. Bulletin No. 9, Institute for Medical Research, Federation of Malaya.

Valkenburg, H. A., and others (1966). Personal communication.

\section{Etudes géographiques de l'arthrite rhumatismale}

\section{RÉSUMÉ}

On compara la fréquence de l'arthrite rhumatismale en huit échantillons des populations de l'Amérique et de l'Europe à l'aide de séries régulières de radiographies des mains et des pieds. Toutes les radiographies furent interprêtées par un observateur.

On ne trouva pas de rapport entre la fréquence de l'arthrite rhumatismale et la latitude géographique.

La fréquence de l'arthrite "définie" ne fut pas significativement différente dans les trois groupes de race 
inclus dans cette enquête, mais la maladie "probable" fut plus commune parmi les Jamaïcains nègres que les Indiens américains ou les sujets de race blanche.

Des signes radiologiques d'arthrite érosive furent plus fréquents chez les Jamaïcains que chez les Indiens américains et plus chez ceux-ci que chez les sujets de race blanche.

Les tests sérologiques pour le facteur rhumatoïde furent plus souvent positifs chez les Indiens américains, chez qui les altérations érosives furent aussi plus accentuées.

On discute la portée possible de ces résultats.

\section{Estudios geográficos de la artritis reumatoide}

\section{Sumario}

Se comparó la frecuencia de la artritis reumatoide en ocho muestras de poblaciones de América y de Europa con la ayuda de radiografías tomadas regularmente deه্ত manos y de pies. Todas las radiografías fueron interpretadas por un observador.

No se encontró relación alguna entre la artritis y la latitud geográfica.

$\mathrm{La}$ frecuencia de la artritis "definida" no fué significativamente diferente en los tres grupos raciales com- $-?$ prendidos en esta investigación, pero la enfermedađo "probable" fué más común en los negros de Jamaica queô en los indios americanos o los sujetos blancos.

Evidencia radiológica de artritis erosiva fué más frecuente en los jamaicanos que en los indios americanosa y más en estos que en los blancos.

Reacciones serológicas para revelar el factor reumatoide $e^{\infty}$ fueron más frecuentemente positivas en indios ameri- $\overrightarrow{0}$ canos, en los cuales las alteraciones erosivas fuerontambién más acentuadas.

Se discuten las implicaciones posibles de estos resulta-o dos. 